\title{
Epidemiological trends of leprosy in Goiás, Brasil
}

\author{
Tendências epidemiológicas da hanseníase em Goiás, Brazil
}

Camila Rodrigues da Silva (https://orcid.org/0000-0002-5032-8042) ${ }^{1}$

Lucas Henrique Ferreira Sampaio (https://orcid.org/0000-0002-2256-1883) ${ }^{2}$

João Paulo Francisco de Souza (https://orcid.org/0000-0002-1860-174X) ${ }^{3}$

Gabriela Tayrine Pereira Caetano (https://orcid.org/0000-0001-6962-8216) ${ }^{2}$

Isabela Jubé Wastoswki (https://orcid.org/0000-0001-5441-4186) ${ }^{2}$
${ }^{1}$ Faculdade de Medicina, Universidade Federal de Goiás. R. 235 s/n, Setor Leste Universitário. 74605050 Goiânia GO Brasil, camilamufg@gmail.com ${ }^{2}$ Programa de Ciências Aplicadas a Produtos para Saúde, Universidade Estadual de Goiás (UEG). Anápolis GO Brasil.

${ }^{3}$ Programa de Recursos

Naturais do Cerrado, UEG. Anápolis GO Brasil.

\begin{abstract}
Brazil is the second nation in absolute number of new cases of leprosy in the world. The country presents many regions highly endemic to the disease, as is the case of the Goiás. The present study aims to analyze the temporal trends of leprosy indicators in Goiás between 2006 and 2015. This study showed a significant trend of decline for the coefficient of detection. Although the central-western region of the state presented the highest absolute number of cases, the Northeast of the state presents the worst epidemiological situation, with an increase in the number of cases of patients with physical disabilities and those under 14 years of age. The data also showed that there is an increase in the cases of patients with physical deformities in almost all macroregions of the state, indicative of late diagnosis. It is very important that there is a more effective and continuous training of the health professionals of the non-centralized units, for a real control of leprosy as a public health problem in the state. In addition, special attention should be given to the poorer regions of the state, which have shown a tendency to increase the diagnosis of patients younger than 14 years and with physical disabilities caused by leprosy. Key words Public health, Endemic diseases, Time series studies, Decentralization
\end{abstract}

Resumo O Brasile é a segunda nação em número absoluto de novos casos de hanseníase no mundo. O país apresenta muitas regiões altamente endêmicas para a doença, como é caso do estado de Goiás. O presente estudo tem como objetivo analisar as tendências temporais dos indicadores de hanseníase em Goiás, entre 2006 e 2015. Este estudo demonstrou uma tendência significativa de declínio para o coeficiente de detecção. Embora a macrorregião do Centro-Oeste do estado tenha apresentado a maior ocorrência absoluta de casos, o Nordeste do estado apresenta a pior situação epidemiológica, com aumento no número de casos de pacientes com incapacidades fisicas e menores de 14 anos. Os dados mostraram, ainda, que há um aumento nos casos de pacientes com deformidades fisicas em quase todas as macrorregióes do estado, indicativo de diagnóstico tardio. É muito importante que haja uma formação mais efetiva e contínua dos profissionais de saúde das unidades não centralizadas, para um controle real da hanseníase como problema de saúde pública no estado. Além disso, uma atenção especial deve ser dada às regiões mais pobres do estado, que apresentaram uma tendência de aumento no diagnóstico de pacientes menores de 14 anos e com incapacidades físicas causadas pela hanseníase.

Palavras-chave Saúde pública, Doenças endêmicas, Estudos de séries temporais, Descentralização 


\section{Introduction}

Leprosy is a chronic infectious disease caused by Mycobacterium leprae. The disease may cause permanent physical disabilities and deformities, leading to severe limitations in individual's ability to perform daily activities ${ }^{1}$. In 1991, WHO called for the elimination of leprosy as a public health problem in the year 2000, defined as the reduction of prevalence in 1 case per 10,000 population ${ }^{2}$. During this period the leprosy prevalence fell from 21.1 per 10,000 inhabitants in 1983 to 0.24 per 10,000 inhabitants in 2000 . Three decades after the introduction of MDT (multidrug therapy) the cases of leprosy have declined significantly in the world and the goal established by WHO has been reached by most countries. This decline occurred due to the generalized use of MDT, in addition to nationwide campaigns and an improvement in the quality of health services directed to leprosy treatment in endemic countries ${ }^{3,4}$.

The total number leprosy new cases registered by the WHO in 2017 was 210,671. Ninety five percent of leprosy cases are concentrated in only 14 countries of high endemicity. Among these countries are India in first place and Brazil coming second in terms of the number of cases detected annually ${ }^{1}$. But Brazil ranks first overall in terms of prevalence around the world ${ }^{2,3}$.

Leprosy remains a substantial public health problem in Brazil, despite improvements in the identification and treatment of cases, with a consequent reduction in incidence. In 2009, 37,610 new cases of leprosy were registered in Brazil ${ }^{3}$. In 2017, the number of new cases dropped to 22,940 . The rate of detection of new cases in the country reached 1.2 per 10,000 inhabitants, still considered "very high" according to the parameters established by the $\mathrm{WHO}^{2}$.

In the Midwest region of Brazil, the indicator in the general population was 3.01 new cases per 10,000 inhabitants. Into the Midwest, Goiás is one of the Brazilian states with the highest number of leprosy reports, presenting 2,3 cases of leprosy per 100,000 inhabitants ${ }^{4,5}$. In this endemic context, the present study aims to analyze the epidemiological patterns and temporal trends of leprosy indicators in the state of Goiás from 2006 to 2015 .

\section{Methodology}

\section{Study area}

The state of Goiás covers 340,086 km2 and it is divided into 246 municipalities. According to the Instituto Brasileiro de Geografia e Estatística (2017) the population in 2010 was over six million inhabitants ${ }^{6}$. According to the Departamento de Informação do Sistema Único de Saúde (2017), the state is divided into five macroregions. Macroregions are divided according to municipalities, population and population density, in order to set minimum levels of health services. The Central-West health macro-region has 72 municipalities, Northeast has 31 municipalities, the North-Central possess 59 municipalities, the Southwest has 28 municipalities and the Central-Southeast macro-region consists of $56 \mathrm{mu}-$ nicipalities.

\section{Study design and population}

The present study is an analytic ecologic study, time series type. It is based on secondary data, coming from the Departamento de Informática do Sistema Único de Saúde (DATASUS), where all the new cases of leprosy of residents in the state of Goiás were included in the period from 2006 to 2015. Data about the year 2016 were not included in the analysis because it was not yet complete until November 2017, in DATASUS, when the main analyzes of the study were reported. The population numbers estimated over the years by IBGE were also collected for statistical purposes. The data were collected from May 1 and June 28, 2017.

\section{Data analysis}

For descriptive analysis, variables were selected according to case records by year (2006 to 2015) and health macroregion. Recorded indicators, recommended by the General Leprosy Coordination and Eliminating Diseases, were as follows: detection coefficient of new cases per 100,000 inhabitants in the general population (magnitude of leprosy); coefficient of detection in children under 14 years, per 100,000 population (active transmission of the disease); proportion of cases with advanced clinical forms (late diagnosis); proportion of paucibacillary cases (early diagnosis) and number of new cases with grade 2 disability detected in a population (sub-detection); and proportion of new cases with grade 2 
disability among all new cases detected during the year (assessment of control program quality).

We used polynomial regression models for the time series. We applied the regression equation that best described the relationship between the dependent variable $(\mathrm{Y})$, corresponding to monitoring indicators, and the independent variable (X), evaluation for leprosy and study year.

The first model tested was a simple linear regression $(\log \mathrm{Y}=\beta 0+\beta 1 \mathrm{X})$. We subsequently tested higher order models including second degree, or parabolic $\left(\log \mathrm{Y}=\beta 0+\beta 1 \mathrm{X}+\beta 2 \mathrm{X}^{2}\right)$, and third degree $\left(\log \mathrm{Y}=\beta 0+\beta 1 \mathrm{X}+\beta 2 \mathrm{X}^{2}+\right.$ $\left.\beta 3 \mathrm{X}^{3}\right)$. The trends were considered statistically significant at $\mathrm{p}<0.05$. For the selection of the best model, we used the principle of parsimony was used, that is, models considering explanatory power $\left(\mathrm{R}^{2}\right)$, meaningfulness ( $\mathrm{p}$ value) and degree $^{7}$. The data were analyzed using $\mathrm{R}$ software, version 3.4.0.

\section{Results}

From 2006 to 2015, a total of 27,711 cases of leprosy was registered in Goiás. The greatest frequency $(3.573,13 \%)$, was recorded in 2006 . The Midwest macroregion had the highest occurrence of cases $(9.562 ; 35 \%)$. The frequencies in the other regions were: Northeast $(2.607,9 \%)$, North-Central (7.030, 25\%), Southwest (2.114, $8 \%)$, Central-Southeast $(6.3092,23 \%)$. In six cases, macroregion was not registered. There was a significantly declining trend for the general detection coefficient (per 100,000 population) $\left(\mathrm{R}^{2}\right.$ : $97 \%, \mathrm{p}=0.000)$. The proportion of paucibacillary cases was stable $\left(\mathrm{R}^{2}: 34 \%, \mathrm{p}<0.043\right.$, Table 1$)$.

A decrease was observed for both the general detection coefficient in children under 14 years of age (per 100,000 inhabitants) $\left(R^{2}=49 \% ; p=\right.$ $0,014)$ (Figure 1), and for the coefficient of detection of cases with grade 2 physical disability (per 100 thousand inhabitants) ( $\left.\mathrm{R}^{2}: 69 \% ; p=0,002\right)$ (Table 1; Figure 2). Stability was also observed in the proportion of leprosy cases with grade 1 of physical disability $\left(\mathrm{R}^{2}: 20 \% ; p=0,253\right)$ (Table 1; Figure 2) and in the proportion of multibacillary cases found $\left(\mathrm{R}^{2}: 32 \% ; p=0,050\right)$ (Table 1; Figure 3 ). Estimates of the population under 14 years of age were taken from DATASUS.

There was a significant reduction of the general detection coefficient of the disease in the state of Goiás. This pattern was homogeneous in most macro-regions of health. Only the Northeast macroregion $(\mathrm{p}=0,650)$ presented stability.
The other regions showed a significant decline in the detection of new cases according to the polynomial regression model for the time series (Table 1). The detection of new cases in children under 14 years of age throughout the historical series presented a significant increase only for the Northeast macroregion $\left(\mathrm{R}^{2}=36 \% ; p=0,039\right)$. Midwest region had a not significant decrease $\left(\mathrm{R}^{2}=13 \% ; p=0,164\right)$. The other regions showed a significant decrease in the detection of new cases in children under 14 years, North center $\left(\mathrm{R}^{2}=\right.$ $89 \% ; p=0,000)$, Southeast $\left(\mathrm{R}^{2}=83 \% ; p=0,000\right)$; Center-South East $\left(\mathrm{R}^{2}=60 \% ; p=0,005\right)$ (Table 1).

The coefficients of detection of new cases of leprosy with grade 2 of physical disability showed stability in two macro-regions: Northeast $(\mathrm{p}=$ $0,054)$ and Center-Southeast $(p=0,073)$. The other macro-regions of health showed a significant decline in the series evaluated. Central-West $(p=0,001)$, North center $(p=0,030)$, Southeast $(\mathrm{p}=0,001)$ (Table 1).

However, the coefficients of detection of new cases of leprosy with grade 1 of physical disability showed significant growth in three macro-regions (Northeast, Center-North and Southeast) and stability trend in the Center-Southeast region. Only the Central-Western macroregion presented a declining trend in cases of patients with physical disabilities grade 1 . Analyzing the general situation of the state, it was also possible to observe a tendency of elevation in the new cases with degree 1 of physical incapacity (Table 1 and Figure 2).

\section{Discussion}

This is a study in which the general detection coefficients of leprosy presented decreasing trends in the state of Goiás, with some patterns tending to stability. The results show that in the last decade there has been a reduction in the number of new cases of leprosy in the state of Goiás, which may have occurred due to the implementation of the Leprosy Control Program in Primary Care ${ }^{8}$ and the Family Health Teams, in most of the municipalities of the state of Goiás 9 . Similar results were observed in previous studies carried out in other Brazilian endemic states, showing a general trend towards a decrease in the incidence of the disease in the different regions of the country ${ }^{10-17}$. However, Brazil is still one of the most endemic countries in the world for leprosy. In fact, the country has not even reached the target preva- 
Table 1. Trend of leprosy indicators in the state of Goiás and its macro-regions of health (per 100 thousand inhabitants), Brazil, 2006-2015.

\begin{tabular}{|c|c|c|c|c|}
\hline Indicator & Model & $\mathbf{R}^{2}$ & $\begin{array}{l}\text { Value } \\
\text { of } P\end{array}$ & Trend \\
\hline General Detection Coefficient & $y=19.15-0.302 x$ & 0,970 & $<0,001$ & Decreasing \\
\hline $\begin{array}{l}\text { Coefficient of detection in children } \\
\text { under } 14 \text { years }\end{array}$ & $y=9.858-0.4417 X$ & 0,493 & 0,014 & Decreasing \\
\hline $\begin{array}{l}\text { Coefficient of detection with degree } \\
2 \text { of physical disability }\end{array}$ & $y=17.393-4.2226 X$ & 0,690 & 0,002 & Decreasing \\
\hline $\begin{array}{l}\text { Proportion of cases with grade } 1 \text { of } \\
\text { physical disability }\end{array}$ & 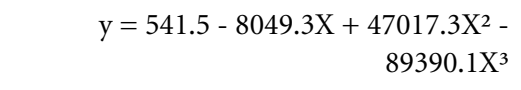 & 0,204 & 0,253 & Stability \\
\hline $\begin{array}{l}\text { Proportion of cases with grade } 2 \text { of } \\
\text { physical disability }\end{array}$ & $y=-151.72+5115.77 X-41145.22 X^{2}$ & 0,324 & 0,105 & Stability \\
\hline Proportion of multibacillary cases & $y=-18.08+31.48 X$ & 0,325 & 0,050 & Stability \\
\hline Proportion of paucibacillary cases & $y=37.94-139.18 x$ & 0,347 & 0,043 & Stability \\
\hline \multicolumn{5}{|l|}{$\begin{array}{l}\text { General detection by macro-regions } \\
\text { of health }\end{array}$} \\
\hline Central-West & $y=16.05-0.22719 x$ & 0,953 & $<0,001$ & Decreasing \\
\hline Northeast & $y=-2102.2+285 X-127.72 X^{2}+18.97 X^{3}$ & 0,224 & 0,650 & Stability \\
\hline North-Central & $y=17.28-0.1714 X$ & 0,821 & $<0,001$ & Decreasing \\
\hline Southwest & $y=16.1841-0.2858 X$ & 0,776 & $<0,001$ & Decreasing \\
\hline Center-Southeast & $y=18.02-0.2523 x$ & 0,912 & $<0,001$ & Decreasing \\
\hline \multicolumn{5}{|l|}{$\begin{array}{l}\text { Detection in children under } 14 \text { years } \\
\text { of age }\end{array}$} \\
\hline Central-West & $y=7.184-0.162 x$ & 0,130 & 0,164 & Decreasing \\
\hline Northeast & $y=1.77+0.6621 x$ & 0,361 & 0,039 & Growing \\
\hline North-Central & $y=11.291-0.411 x$ & 0,892 & $<0,001$ & Decreasing \\
\hline Southwest & $y=10.101-0.6672 x$ & 0,834 & $<0,001$ & Decreasing \\
\hline Center-Southeast & $y=9.24-0.3297 X$ & 0,602 & 0,005 & Decreasing \\
\hline \multicolumn{5}{|l|}{ Case Detection with Grade 1} \\
\hline Central-West & $y=10.230-1.122 x$ & 0,810 & 0,001 & Decreasing \\
\hline Northeast & $y=9.456+1.654 X$ & 0,646 & 0,051 & Growing \\
\hline North-Central & $y=8.765+1.112 x$ & 0,791 & 0,030 & Growing \\
\hline Southwest & $y=12.449+2.804 X$ & 0,788 & 0,001 & Growing \\
\hline Center-Southeast & $y=y=-17.06+29.47 X$ & 0,591 & 0,073 & Stability \\
\hline \multicolumn{5}{|l|}{ Case Detection with Grade 2} \\
\hline Central-West & $y=12.369-2.828 X$ & 0,720 & 0,001 & Decreasing \\
\hline Northeast & $y=102.36-170.63 X+941.574 X^{2}-1654.329 X^{3}$ & 0,545 & 0,054 & Stability \\
\hline North-Central & $y=15.187-2.158 x$ & 0,397 & 0,030 & Decreasing \\
\hline Southwest & $y=12.449-2.804 X$ & 0,762 & 0,001 & Decreasing \\
\hline Center-Southeast & $y=12.2994-1.81606 X-0.02606 X^{2}-0.03465 X^{3}$ & 0,492 & 0,073 & Stability \\
\hline
\end{tabular}

R2: coefficient of determination, how much the model can explain the data (predict). p: chance of obtaining the value in question, the smaller the $\mathrm{p}$ the greater the chance of the model to explain. Tendency: signal that accompanies $\mathrm{x}$ in the equation.

lence goal of 1 case per 10 thousand inhabitants, established by $\mathrm{WHO}^{1}$.

According to the results, the regions of Central-West and Center-Southeastern health showed greater detection of cases in the studied period. Probably they are the most endemic because they make up the areas with the highest population density in the State ${ }^{18}$. Another factor that directly influenced it is the availability of health resources in these two regions, which have a network of medical referral services for the state, which provides an improvement in diagnosis support. In the Center-West region was located the largest Reference Center in the diag- 


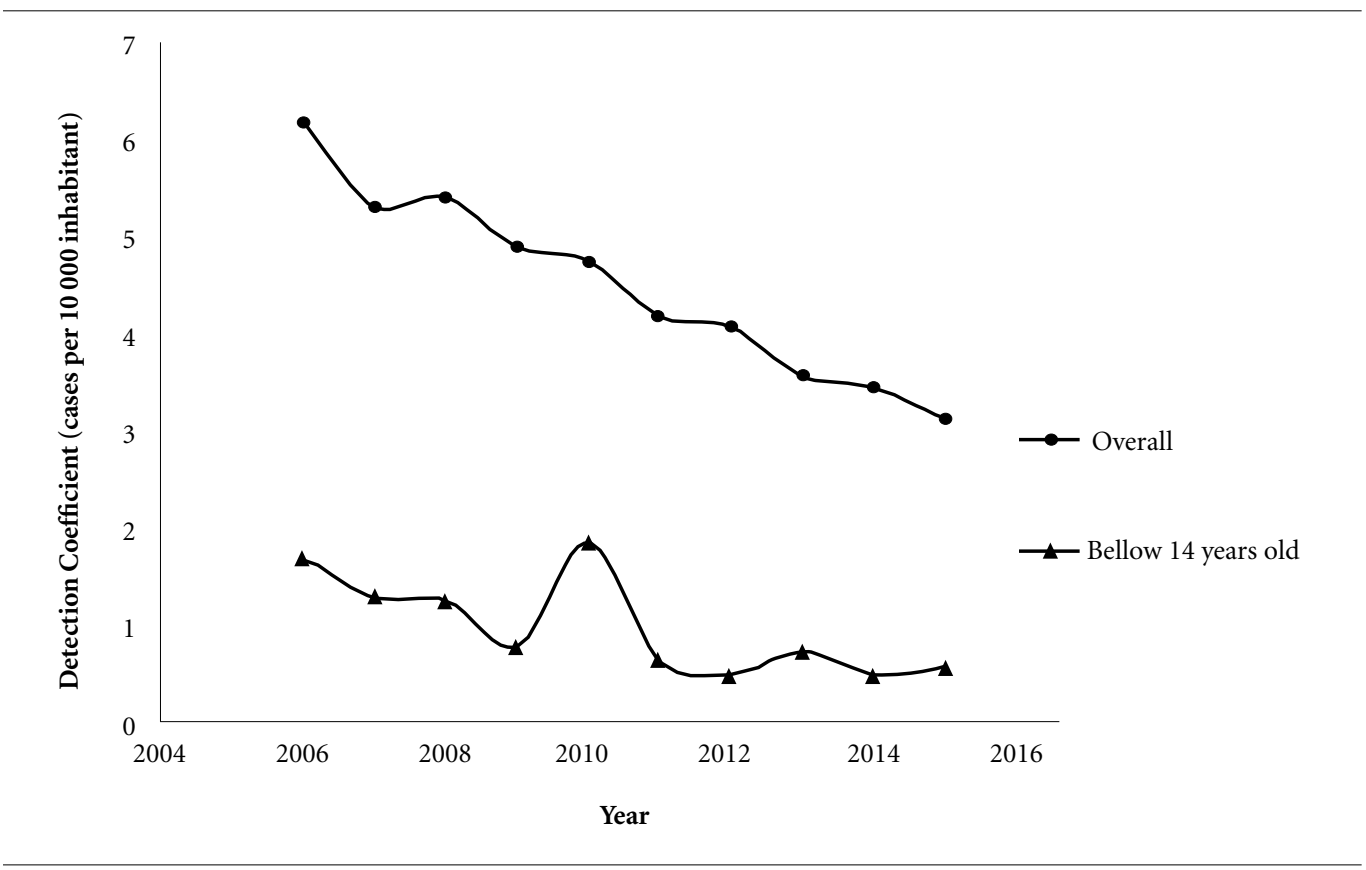

Figure 1. Detection of new cases of leprosy in the general population and in children under 14 years old state of Goiás, Brazil, 2006-2015.

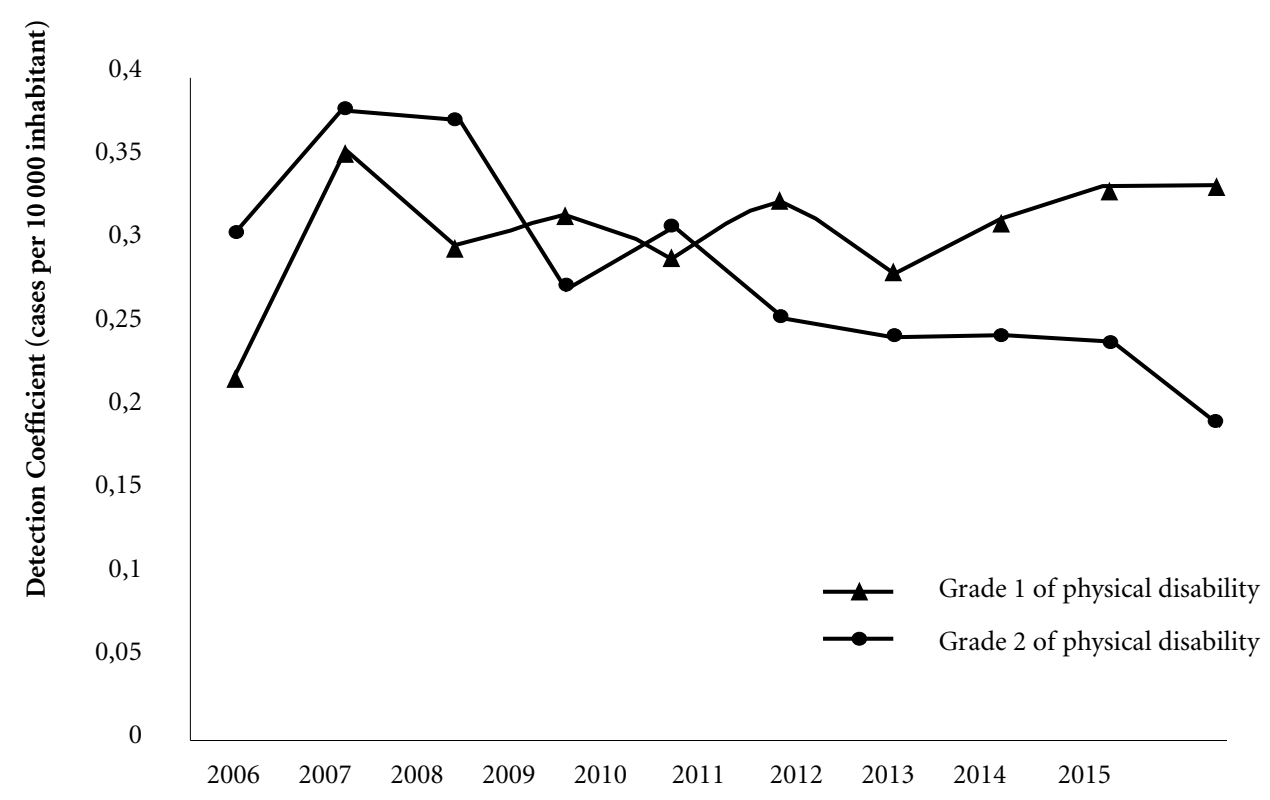

Figure 2. Detection of cases with degrees 1 and 2 with physical disability in the state of Goiás-Brazil, 2006-2015. 


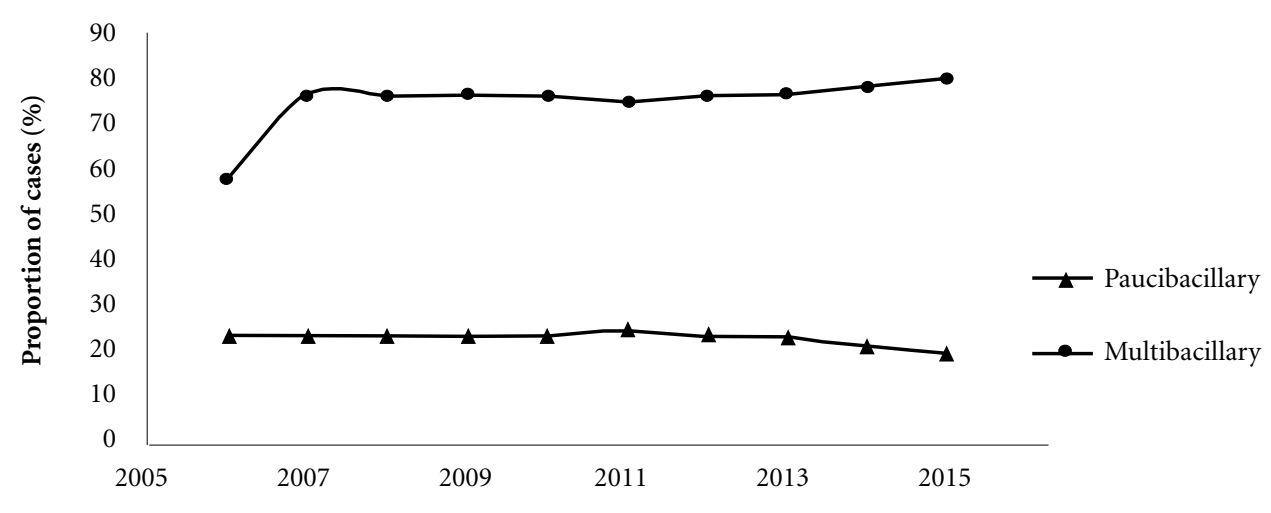

Figure 3. Proportion of cases of leprosy detected in the paucibacillary and multibacillary clinical forms in the state of Goiás, Brazil, 2006-2015.

nosis of leprosy in the state, the CRDT (Centro de Referência em Diagnóstico e Terapêutica) in Goiânia. According to the State Department of Health, CRDT accounted for 58.3\% of all cases diagnosed in the state during the period evaluated. One third of those patients corresponded to individuals referred from the interior ${ }^{19}$.

Although the state of Goiás registers decreases in the prevalence and detection coefficients of new cases of leprosy over the years, there are areas considered more endemic (like Northeast) that deserve greater attention from the government, because cases of leprosy in children under 14 years show recent and active transmission. The Northeast is considered the poorest region of the state, contributing $1.59 \%$ of the Gross Domestic Product (GDP), with few resources in education and health. The northeastern region presented between 2010 and 2015 a coefficient of average prevalence of leprosy 10.4/10.000 inhabitants ${ }^{5}$. Prevalence more than ten higher than that recommended by WHO.

The decentralization is a guiding force in the Sistema Único de Saúde (SUS), being one of its organizational principles. Decentralization is considered a precondition for improving access, participation, quality and equity in the health field ${ }^{20}$. The main actions for the control and elimination of leprosy occur through the decentralization of actions for primary care, where the general practitioner or physician working at the UBS makes the clinical evaluation of the lesion and establishes the diagnosis and consequently the treatment.
When necessary, the UBS sends the patient to a dermatologist or Reference Centers in the diagnosis of leprosy ${ }^{19}$. The decentralization of the diagnosis of leprosy has been taking place in Goiás in a similar way to what has been happening in several places in other Brazilian states ${ }^{21-28}$.

The decentralization of the diagnosis of the reference units to other primary health units, as well as to inner cities, helps to relieve the attendance in the metropolitan regions of the state ${ }^{8}$. However, inversely with the decreasing tendency of general detection, the quantitative of patients with grade 1 of physical disability was significantly increased, indicating the persistence of the late diagnosis and the maintenance of the disease. The increasing trend of cases with grade 1 of physical incapacity generally demonstrates that the diagnosis of the disease is being carried out late ${ }^{29}$. This fact may demonstrate that the decentralization of diagnosis may not be having one of the main expected effects: Accelerate diagnosis. We believe that decentralization and interiorization of diagnosis is a very important step in the control of leprosy. However, interiorization and decentralization must be done with better preparedness and constant training of health teams, which has not been done in the state. And decentralization, without adequate preparation of health professionals, can enable patients to develop permanent physical disabilities and hinders the interruption of the transmission chain.

This study has limitations that are related to the use of secondary data, which may show in- 
consistencies in relation to the quantity, quality and data processing. Despite these limitations, the results show internal consistency, coherence with existing knowledge about leprosy and are highly representative, since they included all notifications of resident cases in the state of Goiás, even when the disease was reported in other states, from 2006 to 2015. Another limitation was the fact that in six cases the macroregion was not registered. However, we believe that these six registries would change very little the results of the study, which took in consideration 27,711 registered cases.

\section{Conclusions}

Goiás has presented a decreasing trend for the detection coefficient of leprosy (2006 to 2015). However, leprosy persists as a serious public health problem in the state, since the number of new cases with some degree of physical incapacity is still very high. There was an expectation that decentralization would facilitate access to leprosy treatment, favoring earlier diagnosis, and improving patient adherence to treatment. However, the analyzed variables did not show a higher precocity of the diagnosis. Quite the opposite. The data showed that an increase in cases of patients with physical deformities continues to occur, indicative of late diagnosis, despite the reduction of the general detection rate. Therefore, it is very important that there is a more effective and continuous training of the health professionals of the non-centralized units, since only then will there be a reduction of patients with physical disabilities and a real control of leprosy as a public health problem in Goiás. A special attention should be given to the Northeastern of the state, since that region has many cases of patients under 14 years, presenting physical disabilities because of leprosy.

\section{Collaborations}

The project was designed and designed by CR Silva, the guiders were IJ Wastoswki and LHF Sampaio. Data collection was performed by CR Silva. The data were statistically analyzed by JPF Souza and LHF Sampaio. The manuscript was written by CR Silva, GTP Caetano, IJ Wastoswki and LHF Sampaio.

\section{Acknowledgments}

We thank the support of the Coordination of Improvement of Personnel of Higher Education (CAPES) the scholarships granted to the students CRS and GTPC, as well as the State University of Goiás (UEG) for the scholarship granted to the student JPFS and the professor LHFS as a Scholarship (BIP), and to the National Council for Scientific and Technological Development (CNPQ) the productivity grant awarded to Professor IJW. 


\section{References}

1. World Health Organization (WHO). Global leprosy update, 2017: reducing the disease burden due to leprosy. Weekly epidemiological record 2017; 35(93):444456.

2. Brasil. Ministério da Saúde (MS). Caracterização da Situação epidemiológica da hanseníase e diferenças por sexo, Brasil, 2012- 2016. Boletim epidemiológico 2018; 22(1):1-55.

3. Penna M, Oliveira M, Penna G. The epidemiological behaviour of leprosy in Brazil. 2009. Lepr Rev 2009; 80(2):332-344.

4. Monteiro LC, Alencar CH, Barbosa JC, Novaes CCBS, Silva RCP, Heukelbach J. Limited activity and social participation after hospital discharge from leprosy treatment in a hyperendemic area in north Brazil. Rev Bras Epidemiol 2014; 17(1):432-441.

5. Barbosa EMA, Freitas DF. Análise descritiva da taxa de prevalência da hanseníase em dois cenários territoriais no Estado de Goiás. Boletim Epidemiológico de Goiás. 2017; 18(4):1-11.

6. Instituto Brasileiro de Geografia e Estatística (IBGE). População de Goiás. 2017. [acessado 2018 Maio 31]. Disponível em: http://www.ibge.gov.br/estadosat/ perfil.php?sigla $=$ go

7. Wassertheil-Smoller S, Smoller J. Biostatistics and Epidemiology a Primer for Health and Biomedical Professionals. $4^{\mathrm{a}}$ ed. Nova York: Springer; 2015.

8. Brasil. Ministério da Saúde (MS). Controle da Hanseníase na Atenção Básica. Normas e Manuais Técnicos. 2001; 111:1-86.

9. Goiás. Plano Estadual de Saúde: 2012 - 2015. 2012. [acessado 2017 Jun 17]. Disponível em: http://www. sgc.goias.gov.br/upload/links/arq_944_planoestadualdesaude2012-2015.pdf

10. Souza EA, Ferreira AF, Boigny RN, Alencar $\mathrm{CH}$, Heukelbach J, Martins-Melo FR, Barbosa JC, Ramos Júnior AN. Leprosy and gender in Brazil: trends in an endemic area of the Northeast region, 2001-2014. Rev Saude Publica 2018; 52:20.

11. Monteiro LD, Martins-Melo FR, Brito AL, Alencar $\mathrm{CH}$, Heukelbach J. Spatial patterns of leprosy in a hyperendemic state in Northern Brazil, 2001-2012. Rev Saude Publica. 2015; 49(84):10-18.

12. Bernardes F Filho, Paula NA, Leite MN, Abi-Rached TLC, Vernal S, Silva MBD, Barreto JG, Spencer JS, Frade MAC. Evidence of hidden leprosy in a supposedly low endemic area of Brazil. Mem Inst Oswaldo Cruz 2017; 112(12):822-828.

13. Miguel LMZ, Jorge MFS, Rocha B, Miot HA. Incidence of skin diseases diagnosed in a public institution: comparison between 2003 and 2014. An Bras Dermatol 2017; 92(3):423-425.

14. Monteiro LD, Mota RMS, Martins-Melo FR, Alencar $\mathrm{CH}$, Heukelbach. Social determinants of leprosy in a hyperendemic State in North Brazil. J. Rev Saude Publica 2017; 20(51):70-79.

15. Nazario AP, Ferreira J, Schuler-Faccini L, Fiegenbaum M, Artigalás O, Vianna FSL.Leprosy in Southern Brazil: a twenty-year epidemiological profile. Rev Soc Bras Med Trop 2017; 50(2):251-255.

16. Gracie R, Peixoto JNB, Soares FBDR, Hacker MAV. Analysis of the geographical distribution of cases of leprosy. Rio de Janeiro, 2001-2012. Cien Saude Colet 2017; 22(5):1695-1704.
17. Freitas BHBM, Cortela DDCB, Ferreira SMB. Trend of leprosy in individuals under the age of 15 in Mato Grosso (Brazil), 2001-2013. Rev Saude Publica 2017; 10(1):51:28 .

18. Goiás. Perfil competitivo das regiões de planejamento do estado de Goiás. 2011. [acessado 2018 Maio 31]. Disponível em: http://www.sgc.goias.gov.br/upload/ anexos/2011-04/f40892f24f7def77a05e7bce682943ff. pdf

19. Goiás. Hanseníase: Análise da Situação Epidemiológica e Operacional de Goiás. 2015. [acessado 2018 Jul 30]. Disponível em: http://www.sgc.goias.gov.br/upload/ arquivos/2016-09/grAficos-indicadores-2016-hansen-.pdf

20. Hortale VA, Pedroza M, Rosa MLG. Operacionalizando as categorias de acesso e descentralização na análise de sistemas de saúde. Cad Saude Publica 2000; 16(1):231-239.

21. Barbieri RR, Sales AM, Hacker MA, Nery JA, Duppre NC, Machado AM, Moraes MO, Sarno EN. Impact of a Reference Center on Leprosy Control under a Decentralized Public Health Care Policy in Brazil. PLoS Negl Trop Dis. 2016; 10(10):e0005059.

22. Porto AC, Figueira RB, Barreto JA, Lauris JR. Evaluation of the social, clinical and laboratorial profile of patients diagnosed with leprosy in a reference center in São Paulo. An Bras Dermatol 2015; 90(2):169-177.

23. Alencar $\mathrm{CH}$, Ramos Júnior AN, Sena Neto SA, Murto C, Alencar MJ, Barbosa JC, Heukelbach J. Leprosy diagnosis in municipalities other than the patients' place of residence: spatial analysis, 2001-2009. Cad Saude Publica 2012; 28(9):1685-1698.

24. Duarte-Cunha M, Souza-Santos R, Matos HJ, Oliveira ML. Epidemiological aspects of leprosy: a spatial approach. Cad Saude Publica 2012; 28(6):1143-1155.

25. Lanza FM, Lana FC. Decentralization of leprosy control actions in the micro-region of Almenara, State of Minas Gerais. Rev Lat Am Enfermagem. 2011; 19(1):187-194.

26. Ximenes FR, Aguiar DT, Martins FR, Benjamim DF, Oliveira ML. An example of political decision to control leprosy in a small municipality in Brazil. Lepr Rev 2010. 81(4):340-341.

27. Fuzikawa PL, De Acúrcio FA, Velema JP, Cherchiglia ML. Factors which influenced the decentralisation of leprosy control activities in the municipality of Betim, Minas Gerais State, Brazil. Lepr Rev 2010; 81(3):196-205.

28. Fuzikawa PL, De Acúrcio FA, Velema JP, Cherchiglia ML. Decentralisation of leprosy control activities in the municipality of Betim, Minas Gerais State, Brazil. Lepr Rev. 2010; 81(3):184-195.

29. Brasil. Ministério da Saúde (MS). Diretrizes para vigilância, atenção e eliminação da hanseníase como problema de saúde pública. Manual Tecnico Operacional. 2016; [acessado 2018 Jul 30]. Disponível em: http:// www.saude.pr.gov.br/arquivos/File/DiretrizesdoManuaTcnicoOperacionaldeHansenase.pdf

Article submitted 06/08/2018

Approved 18/12/2018

Final version submitted 20/12/2018 